\title{
Octospora Hedw., A New Genus Record for Turkish Pyronemataceae
}

\author{
Yasin UZUN $^{1 *}$, İbrahim Halil KARACAN ${ }^{2}$, Semiha YAKAR ${ }^{1}$, Abdullah KAYA ${ }^{1}$ \\ ${ }^{1}$ Karamanoğlu Mehmetbey University, Science Faculty, Department of Biology, Karaman, Turkey \\ ${ }^{2}$ Ömer Özmimar Religious Anatolian High School, Gaziantep, Turkey \\ *yasinuzun_61@hotmail.com
}

\section{Octospora Hedw., Türkiye Pyronemataceae’leri İçin Yeni Bir Cins Kaydı}

\begin{abstract}
The genus Octospora Hedw. is given as new record for the macromycota of Turkey, based on the collection and identification of the taxon Octospora itzerottii Benkert. Brief description of macroscopic and microscopic characters and photographs related to macro and micro morphology of the taxon are provided.
\end{abstract}

Key words: Biodiversity, Octospora, new record, Pezizales, Turkey

Özet: Octospora Hedw. cinsi, Octospora itzerottii Benkert. taksonunun toplanması ve teşhis edilmesi neticesinde, Türkiye makromikotası için yeni kayıt olarak verilmiştir. Taksona ait makroskobik ve mikroskobik karakterlerin kısa betimlemesi ve türün makro ve mikromorfolojisine ilişkin fotoğrafları verilmiştir.

Anahtar Kelimeler: Biyoçeşitlilik, Octospora, yeni kayıt, Pezizales, Turkey

\section{Introduction}

Octospora Hedw is a genus of operculate ascomycetes within the order Pezizales and the family Pyronemataceae Corda. The genus has a cosmopolitan distribution and comprises 84 species (Kirk et al., 2008). The members of the genus are characterized by moss associated apothecia and ellipsoid to globose or rounded, sometimes ornamented, guttulate spores. The hyphal structure of the margin of apothecia is another distinguishing character of the members of the genus (Yao and Spooner, 1996).

Itzerott reports (1977) that the members of Octospora are relatively common in western Europe. Eighty one octosporoid fungi were reported to exist in Europe (Benkert, 2007). But current checklists (Sesli and Denchev, 2014; Solak et al., 2015) and the studies published after the preparation of the checklists (Akata et al., 2016; Denğiz and Demirel, 2016; Sesli et al., 2016; Taşkın et al., 2016; Uzun and Acar, 2016; Uzun et al., 2017) indicate that any member of the genus Octospora have so far been reported from Turkey.

The work aims to make a contribution to the mycobiota of Turkey by adding a new ascomycete taxa.

\section{Materials and Method}

Octospora samples were collected from Nurdağı district of Gaziantep Province in 2015. Ecological and morphological characteristics of the samples were recorded and they were photographed in their natural habitat. Then the samples were brought to the fungarium, dried in air conditioned room and prepared as fungarium materials in polyethylene bags. Micromorphological investigations were carried out under a Nikon eclipse $\mathrm{Ci}$ trinocular light microscope and a DS-Fi2 digital camera and a Nikon DS-L3 displaying apparatus were used for microstructural photographing. The samples were identified mainly with the help of Benkert (1998, 2007, 2009). They are kept at Karamanoğlu Mehmetbey University, Science Faculty, Department of Biology.

\section{Results}

The systematics of the taxon is given in accordance with Kirk et al. (2008), and the Index Fungorum (www.indexfungorum.org; accessed 31 July 2017). A brief description, habitat, locality, collection date, and accession number of the taxon are provided.

\section{Ascomycota Whittaker}

Pezizales J. Schröt.

Pyronemataceae Corda

Octospora Hedw.

Octospora itzerottii Benkert, Öst. Z. Pilzk. 7: 53 (1998)

Macroscopic and microscopic features: Apothecia 1-2.5 $\mathrm{mm}$ in diameter, surface concave at first, later plane to convex or pulvinate, hymenium orange, margin paler and not membranaceous (Fig. 1). Asci 170-260 × 15-20 $\mu \mathrm{m}$, cylindrical, tapering below, mostly 4-spored but also 3-, 5and 6-spored, spores uniseriate. Paraphyses cylindrical, enlarged towards the apex, 5-8 $\mu \mathrm{m}$ wide at the tips (Fig. 2a). Spores 21-26 × 11-13 $\mu$ m, ellipsoid, smooth, with one or two large and several small oil droplets (Fig. 2b).

Ecology: Octospora itzerottii grows on mosses Pterygoneurum ovatum and P. subsessile (Eckstein, 2017).

Specimen examined: Gaziantep, Nurdağı, Kömürler village, mixed forest, on moss (Pterygoneurum ovatum (Hedw.) Dixon), $37^{\circ} 09^{\prime} \mathrm{N}-36^{\circ} 48^{\prime} \mathrm{E}, 535 \mathrm{~m}, 03.04 .2015$, K.11588.

\section{Discussions}

Generally the members of the genera Inermisia, Lamprospora, Neottiella and Octospora within the family Pyronemataceae have tiny, disc-shaped apothecia coloured in shades of orange to red. Due to their small size morphological similarities, they can easily be overlooked and it is very hard to separate their species from each other (Itzerott, 1977). 
Octospora itzerottii is a 4-sporic taxon and has similarities in terms of morphology, ecology and even micromorphology with Octospora crosslandii (Dennis \& Itzerott) Benkert. But the latter species have 8-sporic asci while $O$. itzerottii generally have 4-sporic asci. Medium spore size of $O$. crosslandii $(17-21 \times 10-12)$ is also smaller than that of $O$. itzerottii.

The current checklists (Sesli and Denchev, 2014; Solak et al., 2015) compiled 34 pyronematous macrofungi existing in Turkey. After the latest versions of the checklists 28 members of Pyronemataceae have also been added to these lists and the total taxa number reached to 62 (Keleş et al., 2014; Türkoğlu and Castellano, 2014; Demirel et al., 2015; Karacan et al., 2015; Kaya and Uzun, 2015; Kaya et al., 2016; Kaya, 2016). As a result of this study, the number of pyromenatoid species known from Turkey has increased from 62 to 63 .

\section{Acknowledgements}

The authors would like to thank TÜBITAK for supporting the project (212T112) financially.

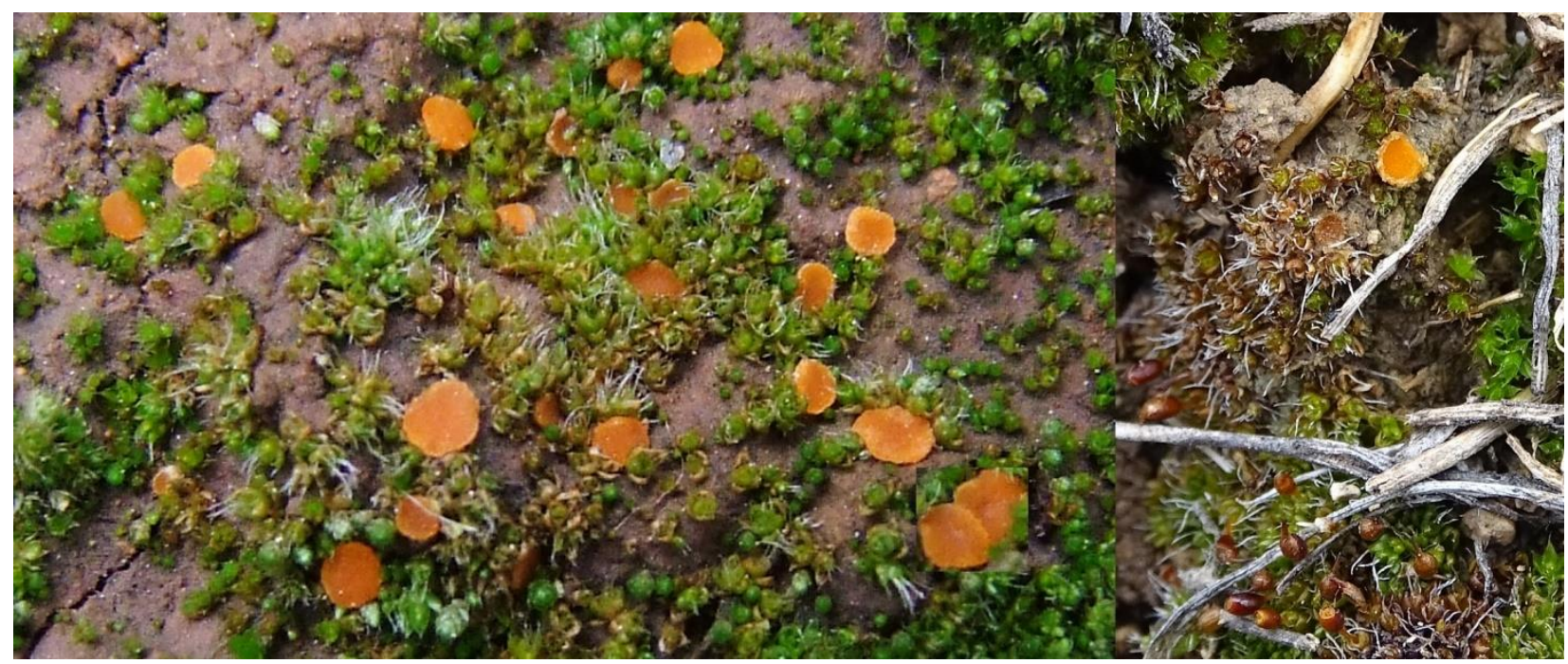

Figure 1. Ascocarps of Octospora itzerottii.

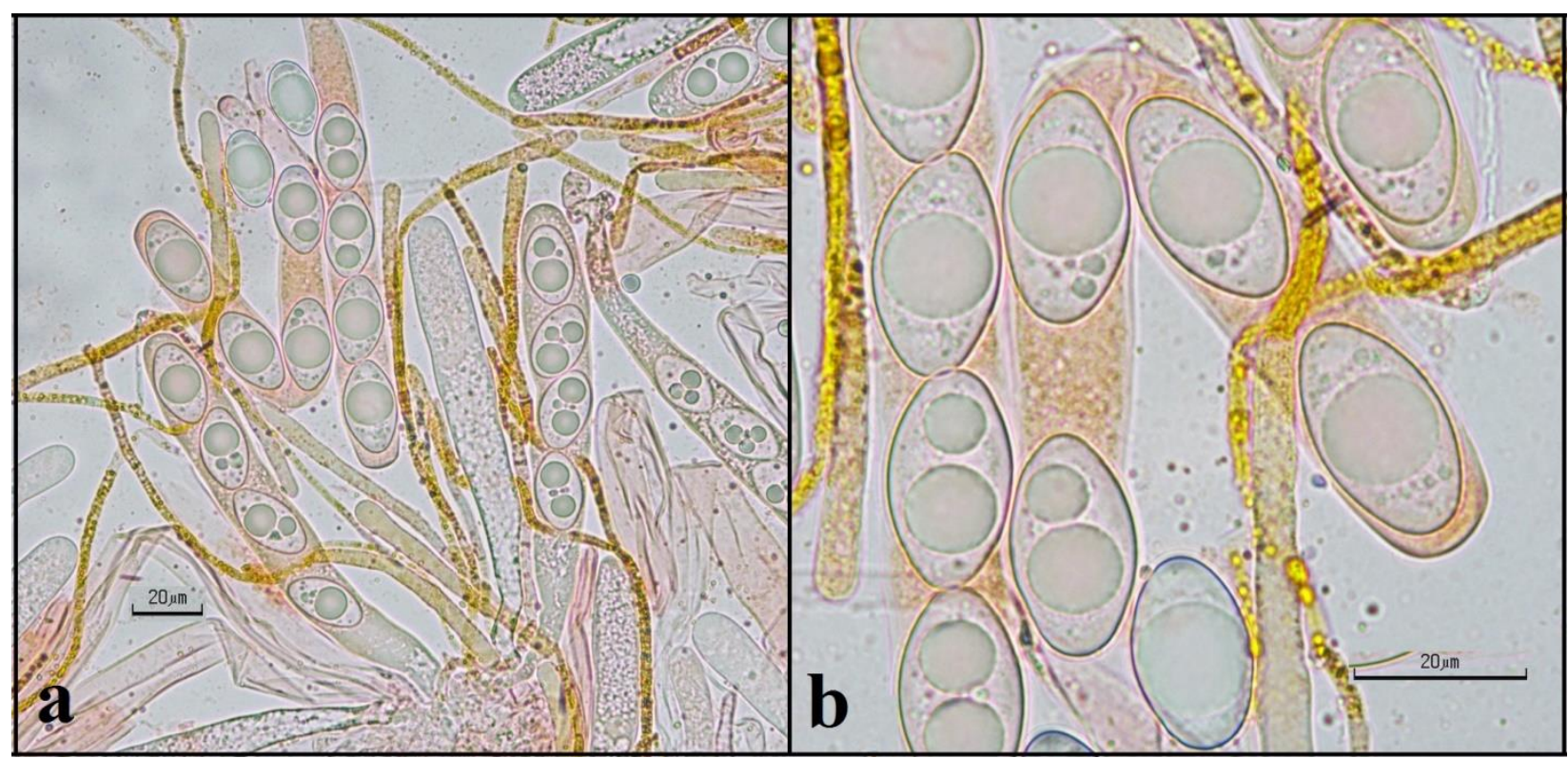

Figure 2. Asci, paraphyses (a) and ascospores (b) of Octospora itzerotti.

\section{References}

Akata I, Uzun Y, Kaya A (2016). Macrofungal diversity of Zigana Mountain (Gümüşhane/Turkey). Biological Diversity and Conservation 9(2): 57-69.

Benkert D (1998). Beiträge zur Kenntnis bryophiler Pezizales-Arten. 8. Viersporige Taxa der Gattung Octospora. Österreichische Zeitschrift für Pilzkunde 7: 39-63.

Benkert D (2007). Zur Kenntnis des Vorkommens bryophiler Pezizales (Ascomycota) in Südost-Europa. Mycologia Montenegrina 10: 7-21. 
Benkert D (2009). Zwei neue Arten bryophiler Pezizales (Ascomycota) aus der Bundesrepublik Deutschland und Auflistung der aus Deutschland bisher nachgewiesenen Arten mit Kurzdiagnostik. Zeitschrift für Mykologie 75: 51 68.

Demirel K, Uzun Y, Akçay ME, Keleş A, Acar İ, Efe V (2015). Van Yöresi Makromantarlarına Katkılar. Mantar Dergisi 6(2): 13-23.

Denğiz Y, Demirel K (2016). Şirvan (Siirt) Yöresinde Yetişen Makrofunguslar Üzerinde Taksonomik Bir Araştırma. Yüzüncü Y1l University Journal of the Institute of Natural \& Applied Sciences 21(2): 112-123.

Eckstein J (2017, October). Octospora itzerottii: Retrieved from the http://octospora.de Web site: http://octospora.de/Oitzerottii.htm

Index Fungorum (2017). http://www.indexfungorum.org/Names/Names.asp. Accessed 31 July 2017.

Itzerott H (1977). The Genus Octospora and an Attempt to Solve Its Taxonomic Problems. Kew Bulletion 31(3): $497-500$.

Karacan İH, Uzun Y, Kaya A, Yakar S (2015). Pulvinula Boud., a new genus and three pulvinuloid macrofungi taxa new for Turkey. Biological Diversity and Conservation 8(2): 161-164.

Kaya A (2016). Contributions to the macrofungal diversity of Atatürk Dam Lake basin. Turkish Journal of Botany 39(1): $162-172$.

Kaya A, Uzun Y (2015). Six new genus records for Turkish Pezizales from Gaziantep Province. Turkish Journal of Botany 39(3): 506-511.

Kaya A, Uzun Y, Karacan İH, Yakar S (2016). Contributions to Turkish Pyronemataceae from Gaziantep Province. Turkish Journal of Botany 40(3): 298-307.

Keleş A, Demirel K, Uzun Y, Kaya A (2014). Macrofungi of Ayder (Rize/Turkey) high plateau. Biological Diversity and Conservation 7(3): 177-183.

Kirk PM, Cannon PF, Minter DW, Stalpers JA (2008). Dictionary of the Fungi. 10th ed. Wallingford, UK: CAB International.

Sesli E, Denchev CM (2014). Checklists of the myxomycetes, larger ascomycetes, and larger basidiomycetes in Turkey. 6th edn. Mycotaxon Checklists Online. (http://www.mycotaxon.com/resources/checklists/sesli-v106-checklist.pdf): $1-136$.

Sesli E, Türkekul İ, Akata I, Niskanen T (2016). New records of Basidiomycota from Trabzon, Tokat, and İstanbul provinces in Turkey. Turkish Journal of Botany 40(5): 531-545.

Solak MH, Işıloğlu M, Kalmış E, Allı H (2015). Macrofungi of Turkey, Checklist, Vol. II. İzmir, Turkey: Üniversiteliler Ofset (in Turkish).

Taşkın H, Doğan HH, Büyükalaca S, Colwez P, Moreau PA, O’Donnell K (2016). Four new morel (Morchella) species in the elata subclade (M. sect. Distantes) from Turkey, Mycotaxon, Volume 131 (2), 467-482.

Türkoğlu A, Castellano MA (2014). New records of some Ascomycete truffle fungi from Turkey. Turkish Journal of Botany 38(2): 406-416.

Uzun Y, Acar İ, Akçay ME, Kaya A (2017). Contributions to the macrofungi of Bingöl, Turkey. Turkish Journal of Botany 41(5): 516-534.

Uzun Y, Acar İ (2016). Peziza granularis Donadini Türkiye Mikobiyotası için Yeni Bir Kayıt. Yüzüncü Yıl Üniversitesi Fen Bilimleri Enstitüsü Dergisi 21(1): 39-42.

Yao YJ, Spooner BM (1996). Notes on British species of Octospora. Mycogical Research 100: 175-178.

Cite this article: Uzun Y, Karacan Hİ, Yakar S, Kaya A (2017). Octospora Hedw., A New Genus Record for Turkish Pyronemataceae. Anatolian Journal of Botany 1(1): 18-20. 